\title{
Gambaran Pemilihan Sumber Air Minum pada Penderita Diare di Desa Kintamani Kabupaten Bangli Bali Tahun 2015
}

\author{
Made Bhuwana Putra \\ Program Studi Pendidikan Dokter, Fakultas Kedokteran Universitas Udayana \\ madebhuwana@gmail.com
}

Diterima: 3 Juni 2016. Disetujui: 15 Juni 2016. Diterbitkan: Agustus 2016

\begin{abstract}
ABSTRAK
Penyebab kematian balita yang masih tinggi hingga saat ini adalah diare. Penyakit diare tersebar pada seluruh kelompok umur dengan prevalensi tertinggi pada anak balita, sebesar $16,7 \%$. Menurut data puskesmas Kintamani I pada tahun 2014 terdapat peningkatan kasus diare sebanyak 216 kasus bila dibandingkan dengan kasus diare pada tahun 2013. Desa Kintamani merupakan desa dengan angka kejadian diare tertinggi pada Kecamatan Kintamani dan mengalami peningkatan dari tahun sebelumnya. Tujuan penelitian ini adalah untuk mengetahui gambaran pola pemilihan sumber air minum pada penderita diare dan non diare di desa Kintamani pada tahun 2015. Dalam melakukan penelitian ini digunakan rancangan penelitian cross-sectional. Populasi penelitian ini adalah kepala keluarga yang memiliki balita di Desa Kintamani. Sampel dipilih dengan menggunakan cara multi-stage sampling, dimana sampel merupakan 54 kepala keluarga yang memiliki balita yang tinggal di Desa Kintamani pada tahun 2015. Penelitian ini dianalisa menggunakan cara deskriptif. Hasil dari penelitian menunjukkan masyarakat yang menggunakan sumber air minum PDAM cenderung mengalami diare dengan nilai 45,5\% jika dibandingkan dengan warga yang menggunakan air kemasan (12,5\%), dan air hujan (37,5\%). Warga yang menggunakan air kemasan cenderung untuk tidak mengalami diare dengan nilai $87,5 \%$ dibandingkan dengan air PDAM (54,5\%) dan air hujan (62,5\%).
\end{abstract}

Kata Kunci: Pemilihan Sumber Air Minum, Diare, Balita

\section{WATER SOURCE SELECTION OF DIARRHEA PATIENTS IN THE KINTAMANI VILLAGE BANGLI REGENCY} BALI 2015

\section{ABSTRACT}

The leading cause of death of toddlers up until now is diarrhea. Diarrhea spread amongst all age with the highest prevalence are among infants $(16,7 \%)$. Based on the data, which is taken from the Kintamani Health Center, the number of diarrhea cases tend to increase from 2013 to 2014. Kintamani village is the village which has the highest number of diarrhea cases compared to neighbor villages in the same region and the number is increasing. The aim of this study is to describe the behavior of the people in Kintamani in 2015 in choosing the source of water to consume in diarrhea and non diarrhea population. Crosssectional design is used in this study and the population of the study was the family head who has toddlers in the Kintamani village and the sample was chosen using the multistage random sampling method. The study was then analyzed descriptively. The result of this study shows that people who consumed municipal water tends to get diarrhea $(45,5 \%)$ compared to those who consumed packaged water $(12,5 \%)$ rain water $(37,5 \%)$. Those who consumed packaged water tend not to develop diarrhea $(87,5 \%)$ compared to those who consumed municipal water $(54,5 \%)$ and rain water $(62,5 \%)$.

Keywords: Water source selection, diarrhea, toddler 


\section{PENDAHULUAN}

Diare dapat diartikan sebagai buang air besar dengan konsistensi lembek hingga cair yang lebih dari biasa (3 kali atau lebih dalam sehari) yang memiliki gejala seperti demam, mual dan muntah, lemah, nyeri perut dan tanda-tanda seperti mata cekung, membran mukosa kering, pucat, pengeluaran urin menurun. ${ }^{1}$ Pada wilayah Asia Tenggara diare menempati urutan kedua dengan angka kejadian 23 juta kasus setiap tahunnya, dengan angka morbiditas dan mortalitas yang tinggi khususnya di Indonesia. ${ }^{2}$ Berdasarkan Survei Kesehatan Rumah Tangga (SKRT), Studi Mortalitas dan Riset Kesehatan Dasar dari tahun ke tahun diketahui bahwa diare masih menjadi penyebab utama kematian balita di Indonesia. Penyebab utama kematian akibat diare adalah tata laksana yang kurang tepat baik di rumah maupun di sarana kesehatan. ${ }^{3}$

Puskesmas Kintamani I merupakan puskesmas yang berada di kecamatan Kintamani Kabupaten Bangli Bali. Puskesmas ini memiliki luas wilayah kerja $78,39 \mathrm{~km}^{2}$ meliputi 8 Desa dan 30 Dusun.

Dilihat dari data pada Puskesmas Kintamani I, kasus diare pada desa Kintamani termasuk dalam 10 besar kasus dengan jumlah kasus adalah 928 kasus selama tahun 2014 dengan peningkatan dari tahun sebelumnya. Desa Kintamani merupakan salah satu 8 desa di Kecamatan Kintamani yang mengalami peningkatan kejadian diare melebihi perkiraan kejadian dalam 1 tahun terakhir dimana pada tahun 2014 mencapai 226 kasus. Faktor - faktor yang mendasari tingginya kasus diare disebabkan oleh 4 faktor yaitu pelayanan kesehatan, lingkungan, masyarakat, dan genetic dimana faktor perilaku kebiasaan masyarakat dengan lingkungan seringkali menjadi faktor predominan terutama pada daerah dengan kesadaran masyarakat yang masih kurang baik. Faktor perilaku memilih sumber air untuk dikonsumsi juga berperan besar dalam kasus diare.,4 Berdasarkan gambaran permasalahan di atas, penelitian ini dimaksudkan untuk memberi gambaran mengenai pemilihan sumber air dan hubungannya dengan kejadian diare di Desa Kintamani.

\section{METODE PENELITIAN}

Penelitian ini dilaksanakan di Desa Kintamani, pada wilayah kerja Puskesmas Kintamani I, Kabupaten Bangli, Bali tahun 2015. Penelitian ini menggunakan rancangan deskriptif observasional dengan desain cross sectional. Pada penelitian ini dilihat gambaran pemilihan sumber air minum pada masyarakat sebagai faktor resiko terhadap kejadian diare sebagai variable dependen.

Populasi dalam penelitian ini adalah semua warga di Desa Kintamani Kecamatan Kintamani Kabupaten Bangli, Bali. Dalam penelitian ini yang menjadi criteria inklusi untuk menjadi sampel adalah masyarakat yang bertempat tinggal di desa Kintamani, Provinsi Bali, bersedia untuk menjadi sampel penelitian, dan tidak cacat secara fisik maupun mental. Pemilihan sampel dilakukan dengan menggunakan teknik Multistage Sampling secara bertahap dimana dilakukan pemilihan banjar secara acak dari desa Kintamani dan kemudian dilakukan randomisasi untuk memilih kepala keluarga yang akan dijadikan sampel penelitian. Data diperoleh secara primer dengan cara observasi dan wawancara langsung terhadap responden berdasarkan kuesioner yang telah dipersiapkan. Data sekunder didapatkan dari Puskesmas Kintamani I untuk mengetahui sebaran diare di Desa Kintamani Kecamatan Kintamani Kabupaten Bangli-Bali. Data yang diperoleh dianalisa secara deskriptif kuantitatif

\section{HASIL PENELITIAN}

Pada penelitian didapatkan 54 kepala keluarga dari 5 banjar di desa Kintamani yang dijadikan responden untuk diobservasi dan diwawancarai. Dari 54 sampel tersebut didapatkan data mengenai sumber air minum yang digunakan responden. Data mengenai pemilihan sumber air minum didapat dengan cara wawancara dengan responden serta observasi langsung. Karakteristik sumber air minum masyarakat desa Kintamani dapat dilihat pada tabel 1. 
Tabel 1. Pemilihan Sumber Air Minum

\begin{tabular}{lll}
\hline $\begin{array}{l}\text { Sumber } \\
\text { Minum }\end{array}$ & Frekuensi & Persentase \\
\hline PDAM & 22 & $40,7 \%$ \\
Air Kemasan & 8 & $14,8 \%$ \\
Air Hujan & 24 & $44,4 \%$ \\
\hline Total & 54 & $100 \%$ \\
\hline
\end{tabular}

Berdasarkan tabel diatas, mayoritas sumber air minum mayoritas masyarakat desa Kintamani adalah berasal dari air hujan yang ditampung oleh warga yaitu sebanyak 44,4 \%. Sedangkan sumber air minum yang minoritas digunakan masyarakat desa Kintamani adalah air kemasan dengan nilai $14,8 \%$

Tabel 2. Sumber Air Berdasarkan Kejadian Diare

\begin{tabular}{llll}
\hline Sumber Air Minum & \multicolumn{2}{c}{ Diare } & \multirow{2}{*}{ Total } \\
\cline { 2 - 4 } & Ya & $12(54,5 \%)$ & 22 \\
PDAM & $10(45,5 \%)$ & $7(87,5 \%)$ & 8 \\
Air Kemasan & $1(12,5 \%)$ & $15(62,5 \%)$ & 24 \\
Air Hujan & $9(37,5 \%)$ & $34(63 \%)$ & 54 \\
\hline Total & $20(37 \%)$ & & \\
\hline
\end{tabular}

Pada tabel 2 disajikkan tabulasi silang antara sumber air minum dengan kejadian diare pada masyarakat desa Kintamani. Pada tabel tersebut dapat dilihat bahwa sampel yang menggunakan sumber air minum PDA cenderung mengalami diare dengan nilai $45,5 \%$ jika dibandingkan dengan warga yang menggunakan air kemasan (12,5\%), dan warga yang menggunakan air hujan (37,5\%). Warga yang menggunakan air kemasan cenderung untuk tidak mengalami diare dengan nilai 87,5\% dibandingkan dengan air PDAM $(54,5 \%)$ dan air hujan $(62,5 \%)$.

\section{PEMBAHASAN}

Pada tabel 5.3, sumber air minum yang mayoritas digunakan oleh sampel adalah dari air hujan dengan persentase sebesar $44,4 \%$. Air dari air hujan ini di tampung dan dialirkan dari pipa di atas menuju tangki air. Kebanyakan air yang ditampung ini dimasak terlebih dahulu baru dipergunakan oleh masyarakat, dan sebagian kecil langsung digunakan oleh masyarakat.

Data tersebut menunjukan terdapat tren dimana pengguna sumber air minum yang berasal dari air kemasan, $87,5 \%$ tidak terjadi diare dan $12,5 \%$ terjadi diare, kemudian pengguna sumber air minum yang berasal dari air hujan $62,5 \%$ tidak terjadi diare dan $37,5 \%$ terjadi diare. Persentase kejadian diare meningkat pada pengguna sumber air minum yang berasal dari PDAM, yaitu sebesar $4 \%$ dan yang tidak terjadi diare $60 \%$. Terdapat tren dimana penggunaan mata air dapat meningkatkan persentase terjadinya diare dibandingkan air kemasan dan air PDAM. Menurut Survei Sosial Ekonomi Nasional oleh Badan Pusat Statistik, sumber air bersih di Indonesia dibagi menjadi sumber yang terlindungi dan tak terlindungi. Sumber air terlindungi dalam penelitian ini adalah air kemasan dan air PDAM, sedangkan yang tidak terlindungi adalah mata air. Berdasarkan data tersebut, terdapat kecenderungan sumber air bersih yang tidak terlindungi memiliki persentase kejadian diare yang lebih tinggi dibandingkan sumber air bersih yang terlindungi. Hal ini dapat terjadi karena parameter kualitas sumber air bersih yang terlindungi selalu dikontrol oleh pemerintah.

\section{SIMPULAN}

Mayoritas sumber air minum responden adalah berasal dari air hujan yang ditampung oleh warga yaitu sebanyak 44,4\%. Sedangkan sumber air minum yang minoritas digunakan responden adalah air kemasan dengan nilai 14,8 \%. Sumber air minum PDAM cenderung mengalami diare dengan nilai $45,5 \%$ jika dibandingkan dengan warga yang menggunakan air kemasan (12,5\%), dan air hujan (37,5\%). Warga 


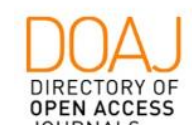

yang menggunakan air kemasan cenderung untuk tidak mengalami diare dengan nilai $87,5 \%$ dibandingkan dengan air PDAM (54,5\%) dan air hujan $(62,5 \%)$. Dengan adanya kecenderungan peningkatan kasus diare pada air yang tidak terlindungi maka penting untuk dilakukan penyuluhan yang ditujukan pada masyarakat desa Kintamani berkaitan dengan pentingnya memilih sumber air minum yang terlindungi dan sesuai standar air minum bersih.

\section{DAFTAR PUSTAKA}

1. Hartojo, A. 2003. Hubungan Faktor-Faktor Lingkungan Keluarga dengan Kejadian Diare di Wilayah Kerja Puskesmas Langensari Kabupaten Ciami, Agustus September 2003. Diakses pada tanggal 18 Februari 2015.
E- ISSN: 2503-3638, Print ISSN: 2089-9084

ISM VOL. 7 NO.1, SEPTEMBER-DESEMBER, HAL 53-56

2. Hung, B.V. 2006. The Most Common Causes and Risk Factors for Diarrhea Among children less than five years of age admitted to Dong Anh Hospital, Hanoi, Northern Vietnam. Diakses pada tanggal 18 Februari 2015.

3. Menteri Kesehatan Republik Indonesia. 2011. Badan Penelitian dan Pengembangan Kesehatan. Departemen Kesehatan RI. Diakses pada tanggal 18 Februari 2015.

4. World Health Organization 2013, Diarrhoeal Disease. Diakses pada tanggal 18 Februari 2015.

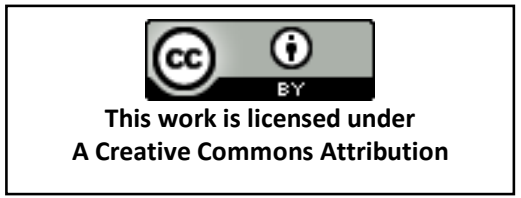

